\title{
大規模事務所建物における故障・不具合の発生件数の特性と 外注の場合を含む修復所要日数に関する調査研究 STUDY ON FEATURES OF OCCURRENCE AND TERM TO REPAIR INCLUDING OUTSOURCING CASE OF FAULTS OR DEFECTS AT LARGE-SCALE OFFICE BUILDING
}

\author{
高草木 明*, 町田勝 美***, 大澤昌志** \\ Akira TAKAKUSAGI, Katsumi MACHIDA and Masashi OHSAWA
}

\begin{abstract}
The aim of this work is to provide data for improving the planning of office buildings maintenance. We got the maintenance record of a large-scale office building that lasts about 11 years since building completion. The record includes the data of 10,937 faults or defects. Using this record data, the features of the occurrence and the term to repair of faults or defects are grasped. The record data include the information about the outsourcing of repair work. This paper also presents the results of the analysis concerning to the outsourcing ratio that will relate to the planning of number of maintenance staffs.
\end{abstract}

Keywords: Office building, Fault, Defect, Maintenance, Outsourcing

事務所建物，故障，不具合，保全，外注

\section{はじめに}

建物では竣工後、建築部位・部材や設備機器等に様々な故障・不具 合注 1) が数多く発生する。この実態に関する知見は、建築を論じる うえで久くべからざる基礎的な知識として蓄積されるべきであろう。

故障・不具合への対応は建物管理者にとって即応を要する優先的 な業務であり、建物の管理において重要な業務である。故障・不具 合の発生とこれへの対応状況の把握は、建物保全現場での保全計画 のための基礎資料として実務的な価值も高い。しかし、これが調査 研究対象となることは稀である。

小松と高草木は、大規模な事務所建物 1 例 ${ }^{1)}$ と中小規模事務所建物 3 例 2) における不具合発生と建物管理者による対応の実態について 保全記録に基づく調查分析を報告している。また、高草木らは某大規 模事務所建物の保全記録データから、保全現場における繁忙状況の故 障・不具合修復に要する時間への影響を明らかにした ${ }^{3)}$ これは、故 障・不具合に対する保全体制（保全人員数）の過不足を評価する方法 の提供を目的としたものである。保全記録デー夕に基づく研究は少な くないが6） 9)、上記の 3 編の論文以外に、故障・不具合全般を対象 とした記録データに基づく研究は見当たらない。

著者らは、上記既往研究に使用したデータとは別の某大規模事務所 建物の保全記録データを入手した。このデータは、建物竣工以来の約 11 年の長期に亘るものであること、故障・不具合の修復業務につい
て外部に委託したものが区分されていること、等が既往研究に用い た保全記録データになかった特徵である。

本研究は、この大規模事務所建物の保全記録データの分析により、 故障・不具合の発生状況の実態把握を行い、基礎的知見の蓄積をはか るとともに、保全体制の計画上重要な知見として備えるべき故障・不 具合の修復業務の外注状況を把握する。保全体制を中心とする保全計 画策定の基礎資料を提供することが本論文の主な目的である注2)。

なお、この調査対象建物を含め 13 件の建物の保全現場で、故障・ 不具合に関わる記録の業務水準について聞き込み調査した。この結果 により、本論文で用いているような保全記録データの存否の状況を示 し、本研究に使用した保全記録データの希少性等を論じた。

\section{1. 本研究に使用した保全記録データの概要}

本研究には、故障・不具合の発生日と処置完了日が含まれている 某大規模事務所建物の保全記録のデータを使用した。表 1 は調查対 象建物の概要及びデータ取得期間である。データ取得期間は 1996 年 10 月 (竣工時) から 2007 年 6 月までの約 11 年間 3, 910 日である。 故障・不具合は建物の部位部材 (以降、建物)、電気設備、衛生設備、 空調設備、機械設備、防災設備、その他に及んでいる。

故障・不具合発生件数の調查期間中の総件数は 10, 937 件である。 些細なものも保全員の稼働が生じたものは全て含まれている。

\footnotetext{
* 東洋大学工学部建築学科 教授・博士 (工学)

***東洋大学大学院工学研究科 博士前期課程

**** (株) NTTファシリティーズ (研究当時, 東洋大学学生)
}

Prof., Dept. of Architecture, Faculty of Engineering, Toyo Univ., Dr. Eng. Graduate Student, Graduate School of Engineering, Toyo Univ. NTT Power and Building Facilities Inc.

(Former Student of Toyo Univ.) 
表 1 調查対象建物概要

\begin{tabular}{|l|l|}
\hline 竣工年月 & 1996 年 9 月 \\
\hline 建物用途 & 事務所、店舗、ギャラリー、飲食店 \\
\hline 所在地 & 東京都 \\
\hline 階数 & 地下 4 階、地上 34 階 \\
\hline 延床面積 & $142,759 \mathrm{~m}^{2}$ \\
\hline データ取得期間 & $\begin{array}{l}1996 \text { 年 } 10 \text { 月 } 1 \text { 日〜2007 年 } 6 \text { 月 } 15 \text { 日 } \\
\text { 観測日数 : } 3,910 \text { 日（閏年を含む） }\end{array}$ \\
\hline その他 & 空調設備はD HCからの熱供給を受けている \\
\hline
\end{tabular}

\section{2．故障・不具合に関する記録業務の水準に関する調査}

建物の現場での保全業務品質の水準には建物によってばらつきが あると考えられる。著者らは文献 ${ }^{4)}$ に細分した保全業務個々の水準を 具体的な仕事の仕方として表現した。この業務水準の分類を用い、表 2 に示寸 13 件の事務所建物において、どの水準で業務がなされてい るかを調查した。この調查は建物の保全を請け負う会社、または保全 現場を訪問し、担当者から直接ヒアリングを行った。建物所有企業は Bビルと Dビルが同じ、他は全て異なる。

本節では、この調查結果の内、故障・不具合の記録の水準に関する 6 つの質問とその回答の結果を示す。

表 2 調查対象事務所建物延床面積 $\left(\mathrm{m}^{2}\right)$

\begin{tabular}{|c|c|c|c|c|c|}
\hline A & 約 160,000 & $\mathrm{~F}$ & 25,462 & & 6,291 \\
\hline B & 142,759 & G & 21,251 & & 5,975 \\
\hline $\mathrm{C}$ & 82,857 & $\mathrm{H}$ & 13,858 & & 約 3,000 \\
\hline $\mathrm{D}$ & 74,827 & I & 11,883 & & \\
\hline $\mathrm{E}$ & 55,556 & $\mathrm{~J}$ & 約 10,000 & & \\
\hline \multicolumn{6}{|c|}{$\begin{array}{l}\text { 延床面積が概数となっている建物は、調査への回答の } \\
\text { 匿名性の徹底を期したいという回答者の意向による。 }\end{array}$} \\
\hline
\end{tabular}

(1)故障・不具合の発生状況の記録の対象について下記の L1〜 L4 の選 択肢を設けてどの水準が採用されているかを質問した。

$\mathrm{L} 1$ : 故障・不具合の状況・原因・処置結果を主なものだけでなく、些 細な故障・不具合についても記録している

$\mathrm{L} 2$ : 主な故障・不具合の状況・原因・処置結果について記録している $\mathrm{L} 3$ : 主な故障・不具合の状況のみ記録している

$\mathrm{L} 4$ : 故障・不具合の状況を記録していない

これに対し、I ビルが L 3 と回答し、他は全て L1 と回答した。多く のビルでかなり詳細な保全記録が残されていることが分かる。

(2)故障・不具合の発生時刻と修復に要した時間の記録については、次 の中からの選択を求めた。

$\mathrm{L} 1$ : 故障・不具合の発生時刻及び修復完了時刻を記録している

$\mathrm{L} 2$ : 故障・不具合の発生時刻のみを記録している

L3:故障・不具合の発生時刻を記録していない

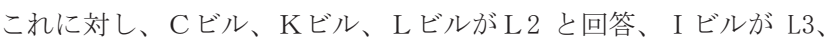
他は全て L1 であった。約 7 割が発生時刻と修復完了時刻とを記録し ている。

(3)現時点で処置を完了していない故障・不具合の保全記録上の管理に ついて次の選択肢を設けた。

L1: 現時点で処置を完了していない故障・不具合を記録し担当者以外

でも情報共有で把握できるようになっている

$\mathrm{L} 2$ : 故障・不具合に対応した担当者のみが把握している

$\mathrm{L} 3$ : 現時点で処置を完了していない故障・不具合を記録していない
この質問には C ビルと Mビルのみが L 2 と回答し、他はL 1 であった。 どのビルでも、保全記録において、処置を終えていない故障・不具合 は分かるようになっている。

(4)修理費、修理依頼先の記録等について次の選択肢を設けて質問した。 L1: 修理費に加え、修理依頼先、修理内容等が記録されており、検索 可能な状態となっていて、他のビルとも情報を共有している

L2: 修理費、修理依頼先、修理内容等が記録されているが、他のビル との情報共有はしていない

L3: 修理費の把握には都度、経理台帳等を調べる

この質問には、F， G， H， I ビルが L1、A， B ， C、J , K , L ビルが L2、D，E，Mビルが L3 であった。約 77\%の保全現場が修理 費等を記録している。

(5)保全記録に基づく非修理系の器具・部品の寿命の把握と予備品管理 に関して次の水準を設定した。

L1: 非修理系の器具・部品について取替えた数量と時期を記録し、寿 命分布を把握して予備品を管理している

$\mathrm{L} 2$ : 非修理系の器具・部品は取替えた数量と時期を記録している

L3: 非修理系の器具・部品は、都度、取り替え、記録していない

これに対し、 E， K， L，Mビルが L2 と回答し、他は L1 と回答し た。約 70\%のビルで蛍光管などの取替えを記録し、予備品管理を行っ ている。

(6)定期点検の成果の分析・評価に関し、次の選択肢を設けた。

L1: 定期点検で発見された不具合が記録され、定期点検の意義が評価 されている

L2: 主要機器のみ定期点検の結果が記録されている

L3: 定期点検の結果が記録されていない

この設問に対し、L，Mビルのみが L2 と回答し、他は全て L1 と回 答した。なお、他の質問から、機器等の定期点検、定期取替えの周期 は調査ビル 13 件全てで計画され決められていることが分かっている。

この調查で、先に挙げた既往研究や本研究に用いているような保全 記録は重要視され高い水準でなされているため珍しいものではない ことが分かった。しかし、Bビル（本研究の調查対象）とDビル（著 者らによる文献 3)の既往研究での調查対象）以外では、データの提供 はできないとのことであった。保全記録データ自体が希少なのではな く、研究に提供されるデータが希少なのである。保全記録データの分 析結果等は公表されることは非常に少なく、当該ビル関係者の間での みの知見に留まっている場合が多い。

本論文に用いたデータは、データの希少性だけでなく、保全記録と しての質が高く、建物保全の模範的な基準值としてのベンチマークを 提供寸るものであるという点の価值も大きいと思われる。

\section{3. 大規模事務所建物における故障・不具合発生の特性 \\ 3. 1 発生件数}

表 1 に示した調查対象建物は表 2 では B ビルである。この建物で 発生した故障・不具合を建物と設備種別毎に分け、それぞれの件数 を比べると図 1 のようになる。建物、衛生設備、空調設備、電気設 備は件数の差が小さくこれらの合計（調查期間総計）で $87.3 \%$ 占 める。空調熱源は地域熱供給を受けているので、熱源設備に関わる 故障・不具合は含まれない。機械設備と防災設備は件数が少ない。

文献 3 の研究に用いた大規模事務所建物（表 2 ではDビル）にお ける同様の故障・不具合件数を 1 日平均、延床面積 $1000 \mathrm{~m}^{2}$ あたり の原単位で比較すると図 2 のようになる。電気設備に顕著な相違が 


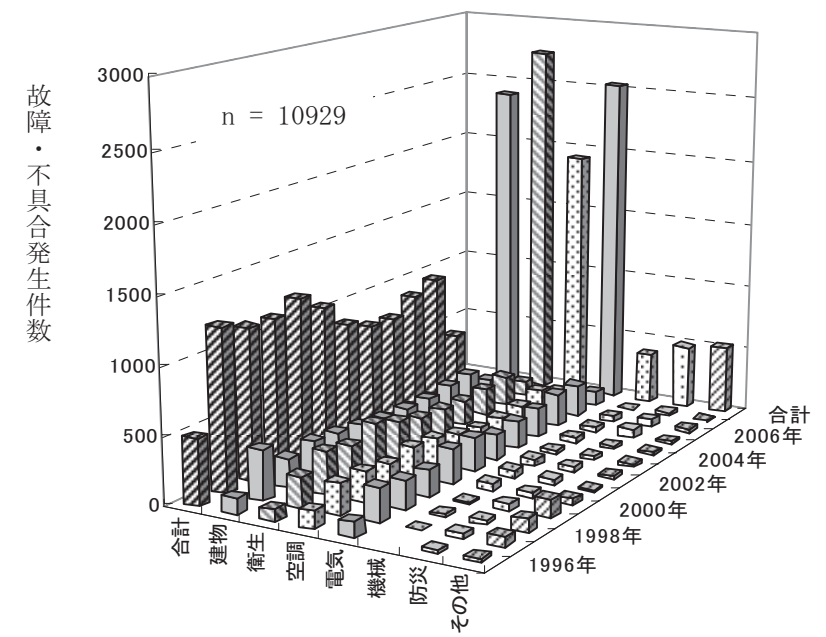

図 1 建物・設備区分別故障 $\cdot$ 不具合発生件数

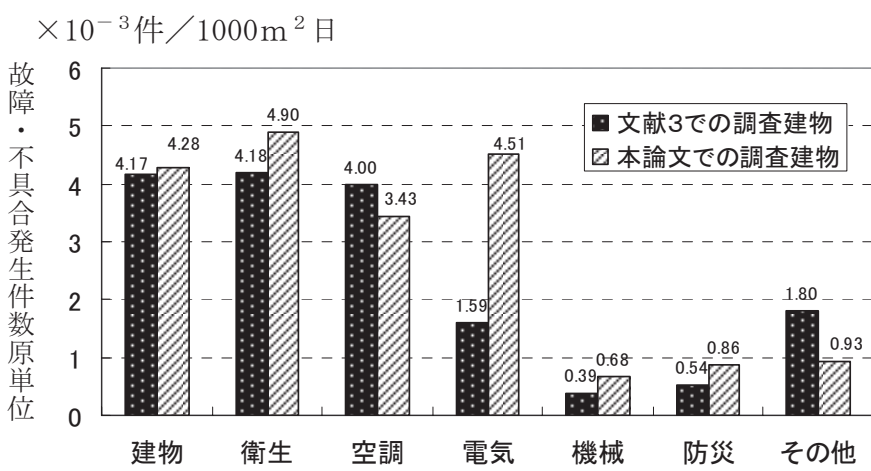

図 2 建物・設備区分別の 1 日平均、延床面積 $1000 \mathrm{~m}^{2}$ あたり故障・ 不具合発生件数 (原単位)

ある。文献 3 の研究に用いたビルはツインタワーの片方の事務所棟 であり、調査対象の保全記録には受変電設備が含まれていない。ま た、ビルオートメーションシステムはリモート側のみが保全記録の 対象でセンターの監視装置は含まれていない。本研究の調查対象建 物は、1 階に店舗（書店）、ギャラリー、地下 1 階にスーパーマーケ ット、飲食店があり、これらの用途では事務室よりも電気設備の故 障・不具合が多い。このような事情により大きな相違が生じている。

なお、照明管球の球切れは別途管理であり、故障・不具合のデー タには含まれていない。

\section{2 発生の時と場所}

図 3 は、曜日別の故障・不具合発生確認件数である。平日の発生確 認件数は、ほぼ同じである。土日は平日に比べると発生確認件数が 少なく、平日の 2 分の 1 以下の件数となっている。

図 4 は、時間帯別の故障・不具合発生確認件数である。9:00〜 15:59 が他の時間帯に比べて発生確認件数が多いが、昼前後の時間帯 $(12: 00$ 〜12:59) には急激に発生確認件数が減少し、ピーク時間帯の件数の 約 4 分の 1 となっている。

最も故障 ・不具合発生確認件数が多いのは、10 時台の 1289 件 $(11.79 \%) 、$ 次いで 9 時台の 1101 件（10.07\%）である。

図 3 、図 4 において、発生確認件数は発生時間の記録によってい

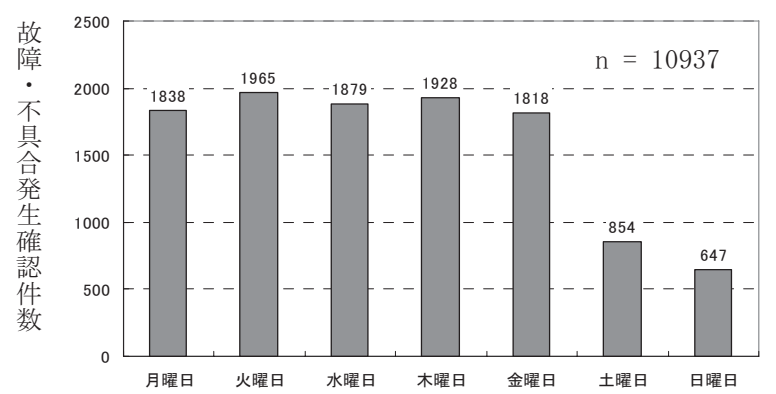

図 3 曜日別の故障・不具合発生確認件数

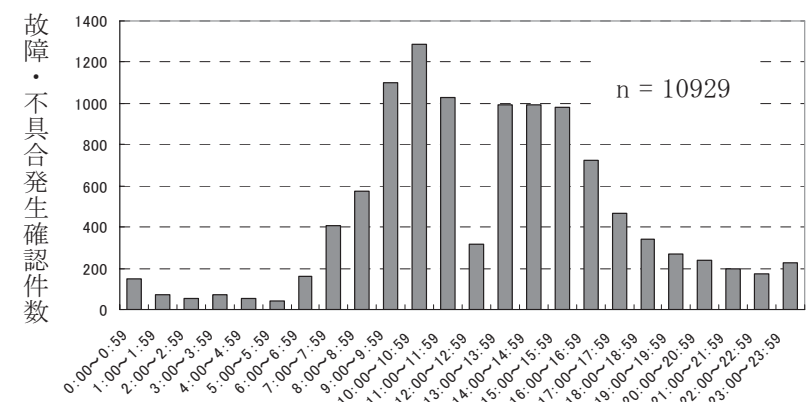

図4 時間帯別の故障 - 不具合発生確認件数

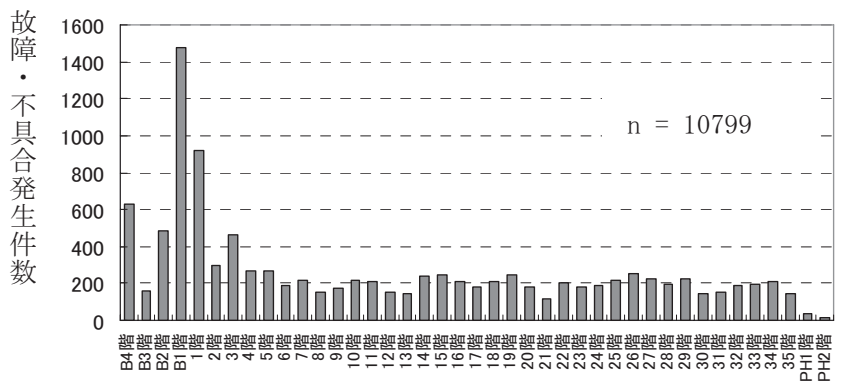

図 5 建物階別の故障・不具合発生件数

る。発生時間とはビル管理者が故障・不具合の発生を認識し、対応 に着手した時間である。従って、この件数には、建物居住者や建物 保全関係者の活動状沉の影響がある注 3)。

図 5 は建物階別の故障・不具合発生件数である。地下 1 階の件数 が 1478 件と最も多い $(13.8 \%)$ 。地下 1 階と 1 階の商業用途では一 般の買い物客や飲食店の客などが多く、故障・不具合発生件数が多 い。地下 $2 \sim 4$ 階には、駐車場、特高の受変電設備、塵芥処理設備 等があり、地下 2 階と地下 4 階では、車路管制装置やこれらの設備 の故障・不具合が多い。

\section{3 発生の発見と通告}

故障・不具合は、建物保全担当者の点検等による「発見」、居住者 からの「申告」、ビルオートメーションシステムからの「アラーム」 のいずれかによってその発生が知らされる。図 6 は設備毎にその割 合を示したものである。防災設備は $74.4 \%$ 占める「アラーム」が 最も多い。これ以外は「申告」による発見が最も多く、建物は $87.8 \%$ 、 衛生設備は $80.6 \%$ 、空調設備は $46.6 \%$ 、電気設備は $51.8 \%$ 、機械 設備は $68.8 \%$ を占める。全体では $65.6 \%$ が「申告」による。「申告」 により発見された故障・不具合は、居住者によって認識された機能、 性能に関わる故障・不具合であり、居住者満足度に影響する要素で ある。 


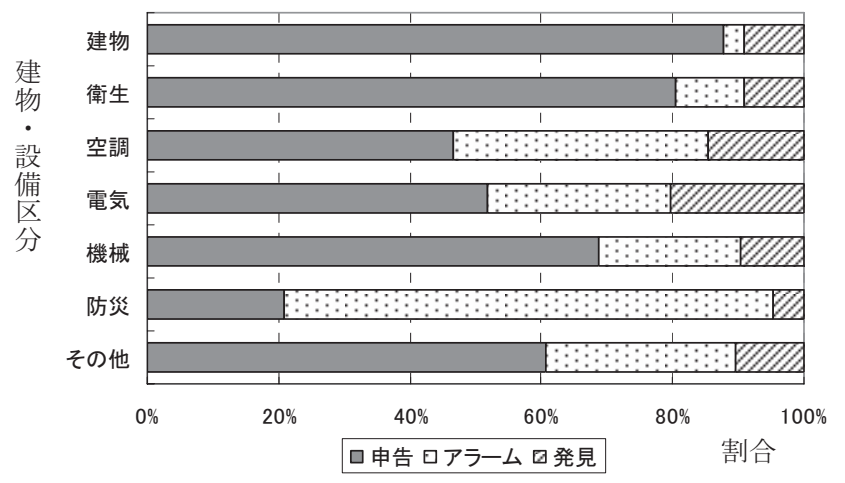

図 6 建物・設備区分別故障・不具合発見区分の割合

\section{4 発生間隔}

故障・不具合の平均発生間隔は、総観測日数／総件数より、0.3573 日となる。延床面積 $1000 \mathrm{~m}^{2}$ 当たりでは、 51.0 日となる。

故障・不具合の間隔は日単位とし、1 日に $\mathrm{k}$ 件 $(\mathrm{k} \geqq 1)$ 発生 している場合には、1／k を間隔データとした。その日最後の $\mathrm{k}$ 番目の故障・不具合から、翌日の最初の故障までの間隔も $1 / \mathrm{k}$ と寸る。翌日以降 $j$ 日間 $(j \geqq 1)$ 発生が無い場合には、前に故 障・不具合が発生した日の $\mathrm{k}$ 番目の故障・不具合から $\mathrm{j}+1$ 日目 の最初の故障までの間隔を $\mathrm{j}+(1 / \mathrm{k})$ とした。表 3 に故障・不 具合の間隔と発生件数の数え方を示寸（解り易さのため、数值は実 態值ではない)。

このようにして求めた故障・不具合の発生間隔について、0.5 日き ざみで度数分布を作成すると図 7 のようになる。信頼性工学において 故障間隔はワイブル分布に従うことが知られている。この分布は、確 率密度関数が、

$$
\mathrm{f}(\mathrm{t})=\mathrm{m} \frac{\mathrm{t}^{\mathrm{m}-1}}{\eta} \exp \left[-\frac{\mathrm{t}^{\mathrm{m}}}{\eta}\right]
$$

$\eta$ : 尺度パラメータ、 $\mathrm{m}$ : 形状パラメータ、

で表される。

尺度パラメータ $\eta$ と平均故障間隔 $\mathrm{t} 。$ との関係は、

$$
\eta=\mathrm{t}_{0} / \Gamma(1+1 / \mathrm{m})
$$

$\mathrm{t}_{0}=0.3573$ として、 $\mathrm{t}$ を 0.5 日きざみとし式(1)を 0.5 の幅 で積分して求めた確率から期待度数を求めた。この場合、図 7 の

\begin{tabular}{|c|c|c|}
\hline 日 & $\begin{array}{l}\text { 故障・不 } \\
\text { 具合番号 } \\
\end{array}$ & $\begin{array}{l}\text { 故障・不具合 } \\
\text { 間隔 }\end{array}$ \\
\hline \multirow[t]{5}{*}{1} & (1) & \\
\hline & (2) & -0.25 \\
\hline & (3) & -0.25 \\
\hline & & -0.25 \\
\hline & (4) & \\
\hline \multirow[t]{3}{*}{2} & (5) & -0.25 \\
\hline & (6) & -0.3333 \\
\hline & (7) & -0.3333 \\
\hline 3 & 発生無し & \\
\hline 4 & 発生無し & \\
\hline & & -2.3333 \\
\hline
\end{tabular}

表3. 故障・不具合の間隔と発生件数の数え方

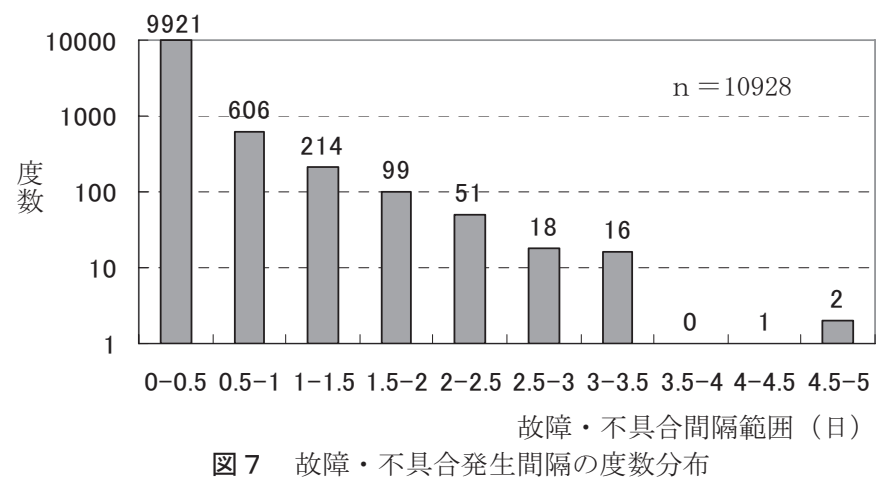

形から形状パラメータ $\mathrm{m}$ は明らかに $\mathrm{m}<1$ である。そこで $\mathrm{m} の$ 值を 0.7 近辺で 0.01 きざみで変えて、期待度数を計算しカイ二乗值を求め たところ、 $\mathrm{m}=0.70$ のとき最小になった。 $\mathrm{m}=0.70$ のときの計算結 果を表 4 と図 8 とに示す。ただし、自由度 9 で $1 \%$ 有意のためには $\chi$ ${ }^{2} \leqq 21.7$ でなければならないから適合性は棄却される。しかし、図8 から分かるように決してかけ離れてはいない。

$96 \%$ 以上が発生間隔は 1 日以内であり、周期性は無く、ランダムな 発生でもない。ランダムに発生する場合 $(m=1)$ に比べれば、間隔が 1 日以上の場合の度数割合が高い。

表 4 故障・不具合発生間隔の実態度数と期待度数

\begin{tabular}{|c|c|c|c|c|}
\hline $\mathrm{t}$ の範囲 & 実態度数 & 確率 & 期待度数 & $\chi^{2}$ \\
\hline $0-0.5$ & 9921 & 0.8889 & 9714.01 & 4.41 \\
\hline $0.5-1$ & 606 & 0.0840 & 918.12 & 106.11 \\
\hline $1-1.5$ & 214 & 0.0199 & 217.34 & 0.05 \\
\hline $1.5-2$ & 99 & 0.0059 & 64.25 & 18.80 \\
\hline $2-2.5$ & 51 & 0.0020 & 21.52 & 40.37 \\
\hline $2.5-3$ & 18 & 0.0007 & 7.84 & 13.15 \\
\hline $3-3.5$ & 16 & 0.0003 & 3.04 & 55.17 \\
\hline $3.5-4$ & 0 & 0.0001 & 1.24 & 1.24 \\
\hline $4-4.5$ & 1 & 0.0000 & 0.53 & 0.43 \\
\hline $4.5-5$ & 2 & 0.0000 & 0.23 & 13.62 \\
\hline 計 & 10928 & 1.0018 & 10948.13 & 253.34 \\
\hline
\end{tabular}

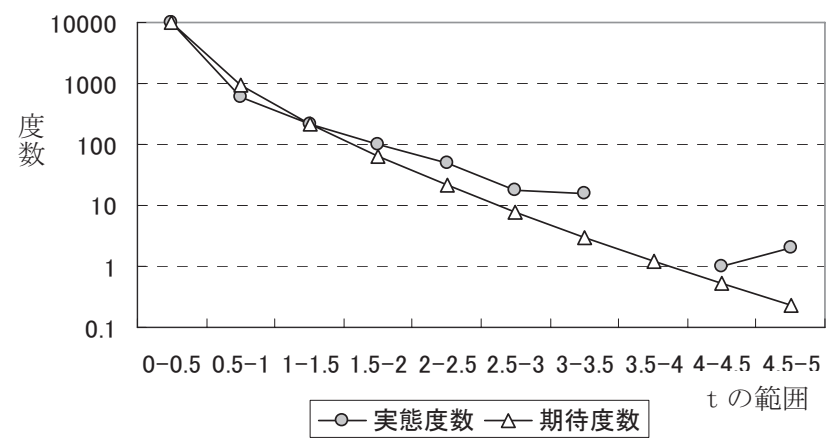

図 8 実態度数と期待度数

\section{5 初期故障期}

図 9 は、調查期間中の月毎の故障・不具合発生件数の推移である。 建物全体での故障・不具合発生件数では、竣工後 3 ケ月、電気設備 は竣工後 2 ケ月、空調設備は䇋工後 3 ケ月の件数が多く、初期故障 期の故障率低減傾向が明確に認められる。衛生設備にはそのような 特徵は見られなかった。

建物の保全では初期故障期には特別な人員体制が採られることが 多い。従って、保全計画上その実態を把握することは極めて重要で 


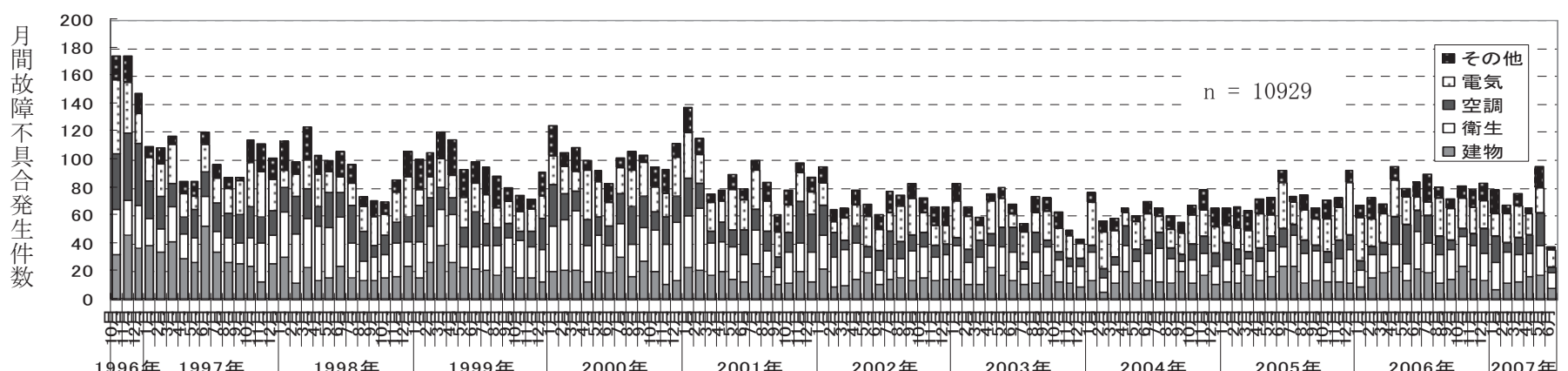

図 9 調查期間中の月毎の故障・不具合発生件数の推移

ある。初期故障期の故障率低下の時系列変化は、ワイブル分布にお ける形状パラメータ $\mathrm{m} か ゙ \mathrm{~m}<1$ のとき故障率関数が下に凸の単調減 少となることから、これを当ててモデルとして表現される。バスタ ブカーブと呼ばれる故障率のライフサイクルモデルの一部（初期故 障期）である。

故障率は、ある時点まで動作してきたアイテムが引き続く単 位時間内に故障を起こす割合であり、瞬間故障率と平均故障率 がある。実際のデータから故障率を観測するには、平均故障率を次 式から求める5)。

平均故障率 $=$ 期間中の総故障数 $/$ 期間中の総動作時間 $\cdots(3)$

月毎の場合は竣工後 1 年間（1996 年 10 月〜1997 年 9 月）では、 図 10 のようになる。縦軸は延床面積 $1000 \mathrm{~m}^{2}$ あたり月間件数として いる。平均故障率 $\Lambda(\mathrm{t})$ は瞬時故障率とは定義が異なり、信頼度関数 と関連しない。従って、当てはまりのよい単純な減少形の関数を見 出せばよい。対数関数が比較的よく当てはまり、その回帰式は、

$$
\begin{gathered}
\Lambda \quad(\mathrm{t})=-0.27471 \mathrm{n}(\mathrm{t})+1.2665 \\
\mathrm{t}=1,2, \cdots, 12 \text { (竣工以来の月次) }
\end{gathered}
$$

となり、決定係数は $\mathrm{R}^{2}=0.8093$ となった。

初期故障期における月次の平均故障率の变化が、実態データに基づ く回帰式として捉えられた注4)。

\section{4. 修復の所要日数と外注}

\section{1 修復に要した日数の分布と外注状況}

図 11 は修復に要した日数の分布を示したものである。多くは 1 日で修復が終わっており（有効件数の $88.2 \%$ ）、修復日数が

$$
\text { 件 } / \text { 月 } \cdot 1000 \mathrm{~m}^{2}
$$

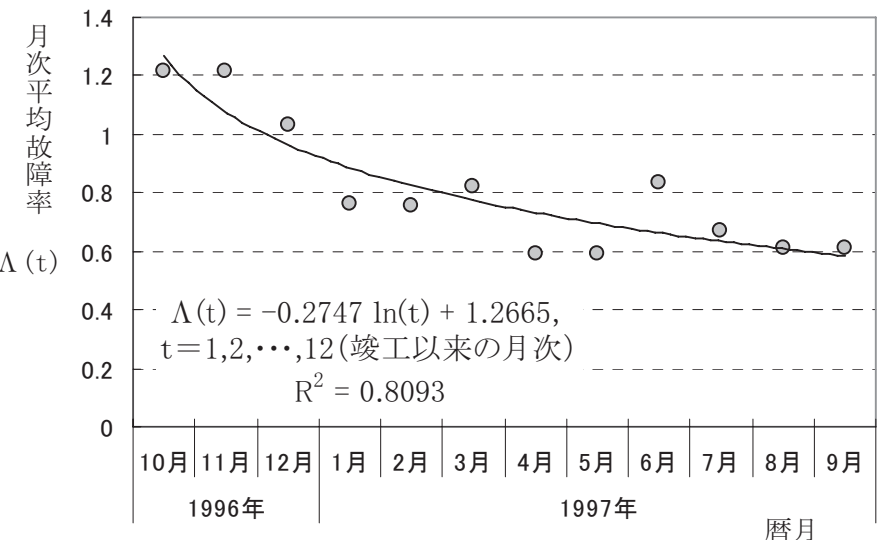

図 10 竣工後 1 年間の月次の平均故障率とその回帰曲線
増えるごとに件数は少なくなっている。また、31 日以上要したもの も 96 件ある。信頼性工学においては、故障修復時間の分布は対数正 規分布によく当てはまることが知られている。このデータは日単位 なので対数正規分布への当てはめはできないが、大方の故障は短時 間で復旧するが、修復に長時間要するものも少数存在する」という 定性的な特徽の説明は共通寸る注 5)。

建物・設備それぞれの故障・不具合件数を外注と非外注に分けて 示したものを図 12 に示す。各設備の故障・不具合の外注割合は、建 物と衛生設備がともに $23.2 \%$ 、空調設備が $20.1 \%$ 、電気設備が $21.0 \%$ 、機械設備が $65.4 \%$ 、防災設備が $14.8 \%$ であり、エレベータ を含む機械設備のみが $50 \%$ を超えている。

原因別の故障 - 不具合発生件数の外注 - 非外注別の割合を図 13 に示す。外注割合は、設備故障（機械的・電気的故障）が $54.5 \%$ 、 人為故障が $16.4 \%$ 、劣化故障が $30.0 \%$ 、原因不明が $22.2 \%$ となっ ており、設備故障の外注割合のみが $50 \%$ 超えている。

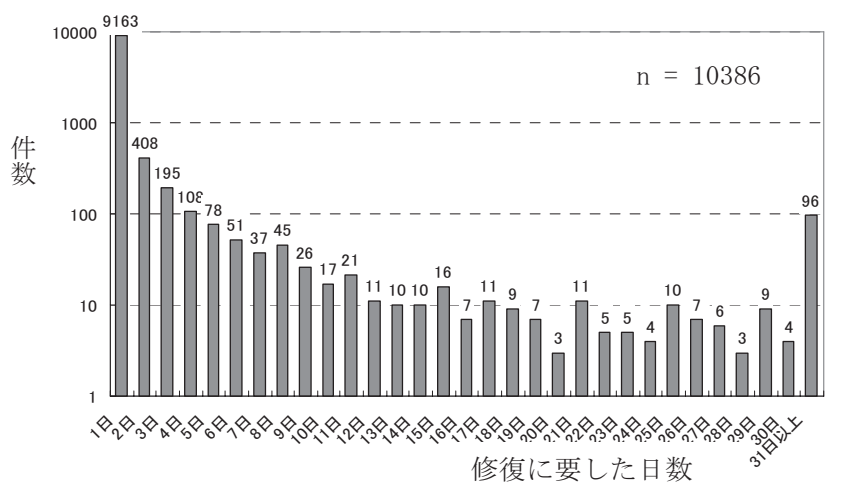

図 11 故障・不具合の修復に要した日数の分布

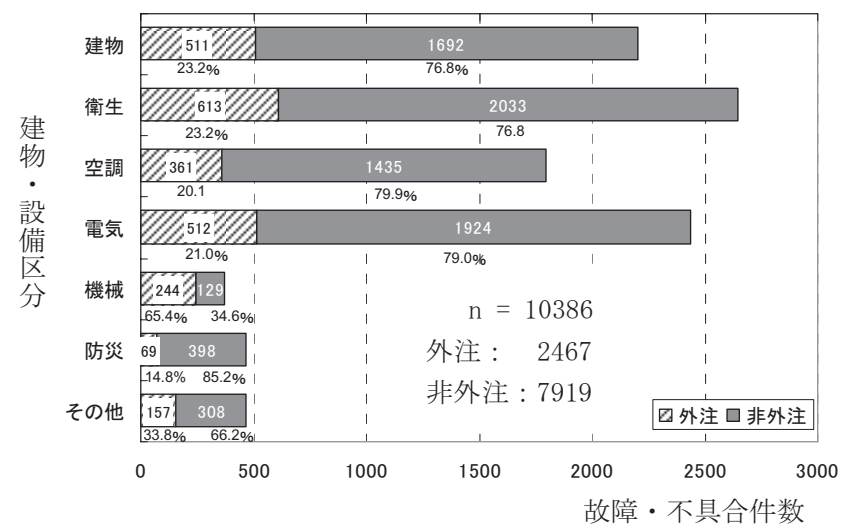

図 12 故障 - 不具合の建物 ・設備区分別外注件数と割合 


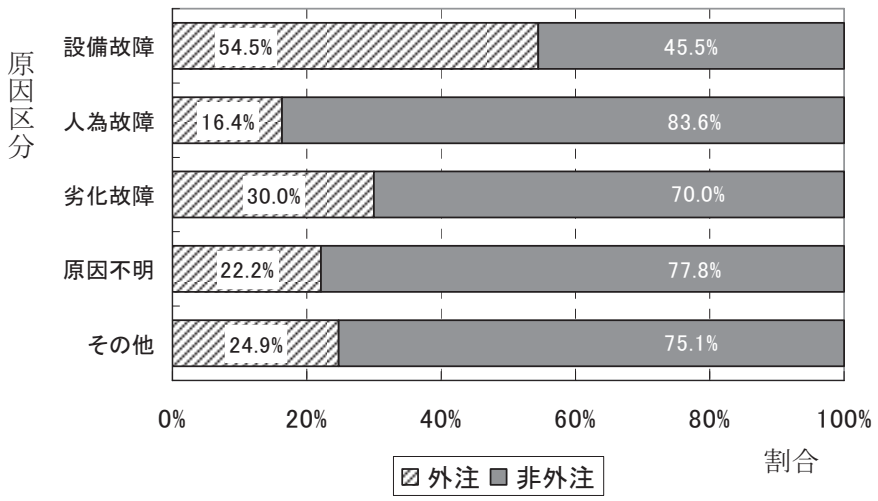

図 13 原因別の故障・不具合発生件数の外注・非外注割合

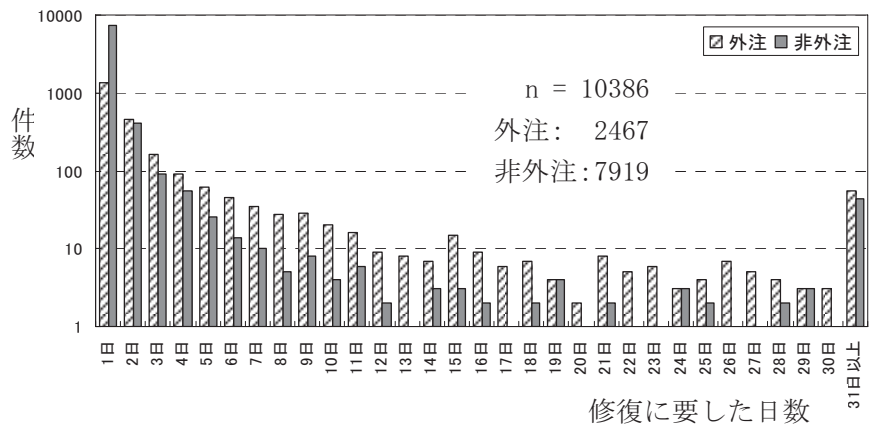

図 14 外注、非外注別の修復に要した日数の分布

修復業務を外注した場合と外注せずに修復を行った場合に分け、 修復までの日数の分布を示したものが図 14 である。修復日数の単純 平均は、外注が 5.32 日、非外注が 2.26 日となり、平均的には修復 業務を外注した場合のほうが、修復完了するまでに倍以上の日数を 要している。修復日数の分布の形も大きな相違が認められる。

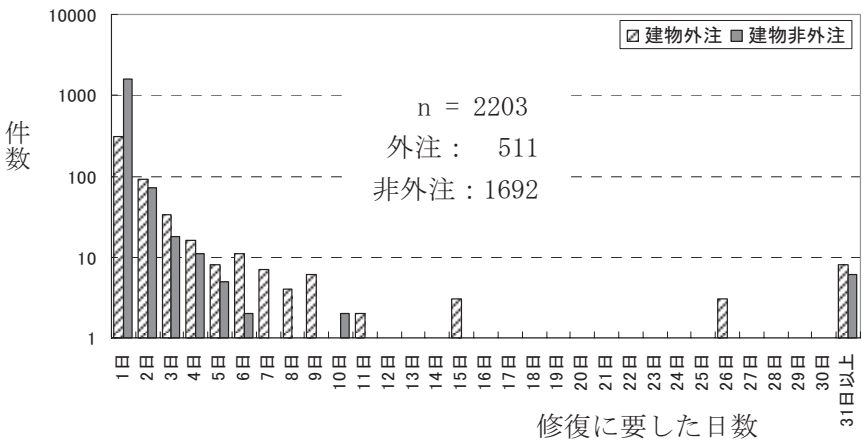

図 15 外注、非外注別の修復に要した日数の分布（建物）

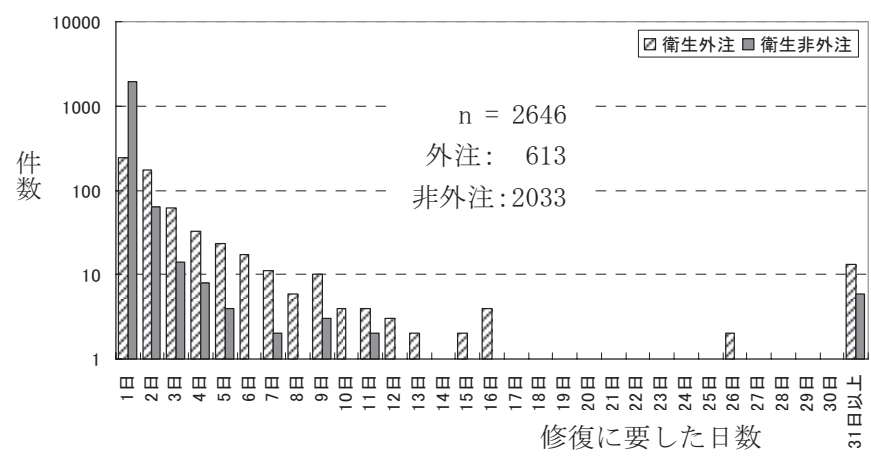

図 16 外注、非外注別の修復に要した日数の分布（衛生設備）

\section{2 建物・設備種別毎の外注 · 非外注の修復日数の相違}

図 15 は、建物の修復について修復業務を外注した場合と外注しな かった場合に分けて修復までの日数の分布を示したものである。修 復日数の単純平均は、外注が 3.88 日、非外注が 1.90 日となってい る。外注の場合でも 10 日以上かかる修復は少ない。

図 16 は、衛生設備の修復について修復業務を外注した場合と外注 しなかった場合に分けて修復までの日数の分布を示したものである 修復日数の単純平均は、外注が 5.04 日、非外注が 1.50 日となって いる。建物の場合と似て、10 日以上かかる修復は少ない。

図 17 は、空調設備の修復について修復業務を外注した場合と外注 しなかった場合に分けて修復までの日数の分布を示したものである。 修復日数の単純平均は、外注が 8.71 日、非外注が 1.84 日となって いる。外注の修復については、即日修復が終了する場合の割合が小 さく、修復に 10 日〜30 日程度を要する場合が多いことが曊著な特 徵である。

図 18 は、電気設備の修復について修復業務を外注した場合と外 注しなかった場合に分けて修復までの日数の分布を示したものであ る。修復日数の単純平均は、外注が 5.05 日、非外注が 3.50 日とな っている。非外注の場合の修復日数が他に比べて顕著に長い。

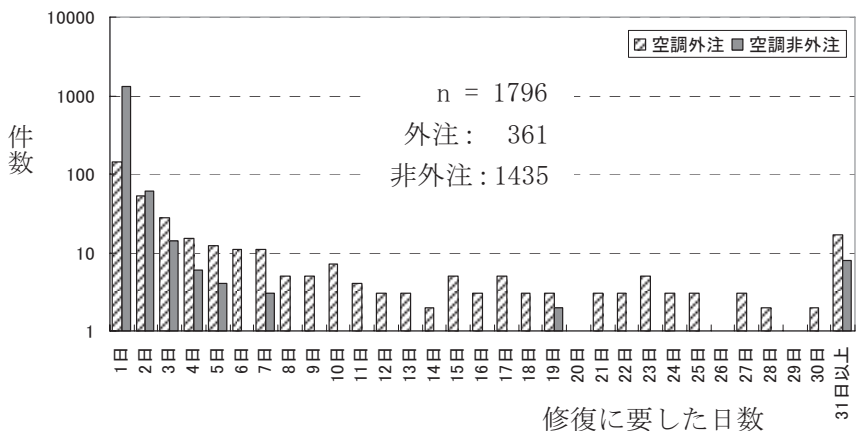

図 17 外注、非外注別の修復に要した日数の分布（空調設備）

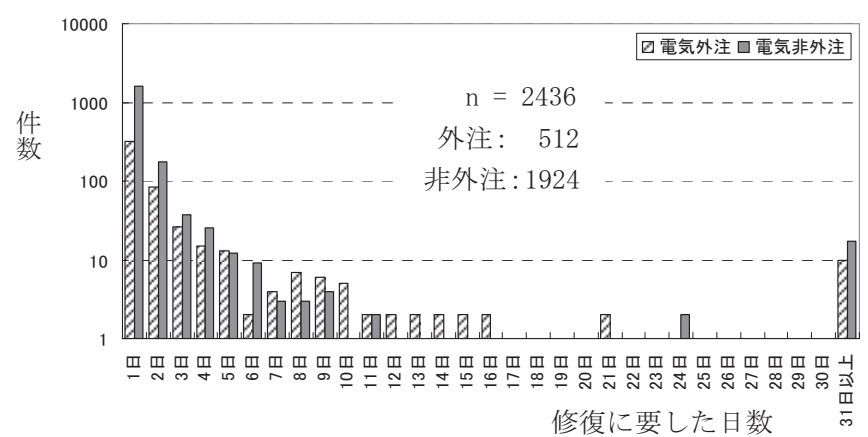

図 18 外注、非外注別の修復に要した日数の分布（電気設備）

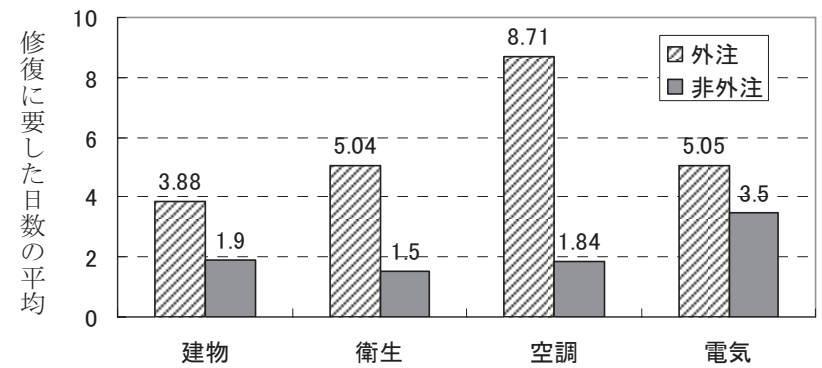

図 19 建物・設備種別による平均修復日数の外注・非外注での比較 
図 19 は、建物、衛生、空調、電気それぞれの平均修復日数の外 注、非外注での比較である。建築、各設備いずれにおいても修復を外 注しているものの方が日数がかかっている。外注の場合、外注先への 連絡や駆け付けに要する時間が影響する。また、本格的な工事が必要 であったり、専門技術を要するような故障・不具合の場合に外注して いるため、日数がかかっていると考えられる。特に空調設備において 顕著である。電気設備は非外注の場合に平均修復日数が長く外注の場 合と大差が無い。空調では故障修理に工事を伴うことが多く、電気で は非外注の場合でも、停電作業のために修復に日数がかかる場合が多 いと考えられる。

\section{3 故障・不具合のモード区分別の修復外注率}

図 20 は、故障・不具合のモード区分別の件数を外注と非外注の件 数を分けて示したものである注 6)。動作不能での故障が 2683 件と最 も多く、機能低下の 1295 件、水漏孔の 970 件、破損の 817 件、異常 動作の 721 件、と続いている。

外注割合が $50 \%$ 以上のものはガス漏れの $100 \%$ （但し 1 件のみ）、 読值異常の $78.9 \%$ 、制御不能の $58.5 \%$ 、蒸気漏孔の $50 \%$ であった。

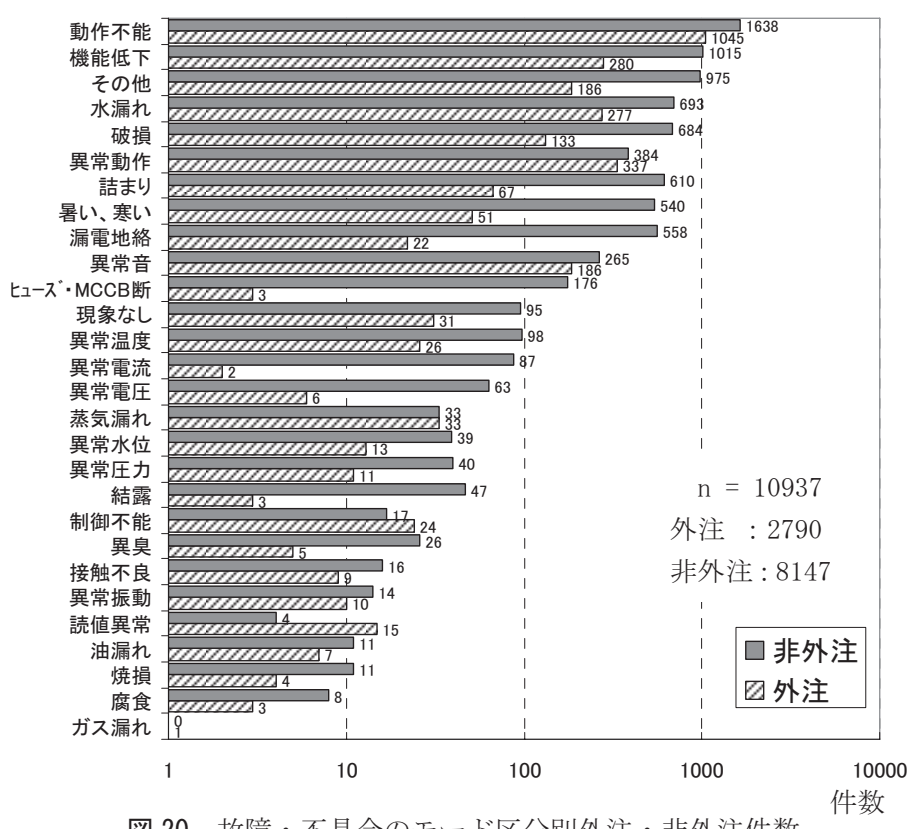

\section{4 空調設備のサービスメンテナンスの利用状況}

建築設備機器の故障対応の保全は、当該機器の製造メーカーあるい はその関連会社が担うことが多い。製造技術に基づく保全であり、「サ ービスメンテナンス」と呼ばれている。衛生設備は、ポンプなどにサ ービスメンテナンスが適用されることがあるが、多くは空調設備が対 象となる。

図 21 は空調設備の故障・不具合の修復を外注した総件数 363 件の 外注先の割合である。この調查対象ビルでは、空調熱源は地域熱供給 を受けている。このため熱源機器が無く、機器メーカーによるサービ スメンテナンスの内容は、VA Vユニットが最も多く、他に、空調機、 ファンモータ、熱交換器などが対象である。バルブなどの配管付属機 器の関連業者による修理、交換などはサービスメンテナンスに含めず、 その他に分類している。計装会社のメンテナンスもサービスメンテナ

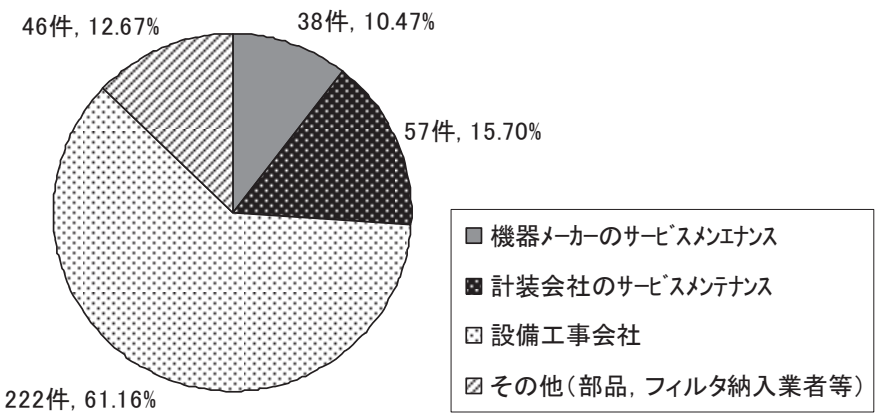

図 21 空調設備の外注修復の外注先割合

ンスに含まれると考えられる。これは $15.7 \%$ 占めている。

地域熱供給を受けている空調設備では、サービスメンテナンスの割 合は小さく、外注する場合の $26 \%$ に過ぎない。 $61.16 \%$ が設備工事会 社に発注されている。

本研究に使用した保全記録データは EXCEL 上において、故障・不具 合 1 件毎に 1 行を使い、発生時間、修復完了時間、事象の状況、外注 先等々のデータが残されている。約 11 年間、10,937 件の多量の記録 であるから、中には若干の久落（空欄）や明らかな入力ミスなどがあ る。本論文の図中に示したデータ数の若干の相違は、それぞれの分析 目的に対し、記録にこのような不備のある故障・不具合データを除い たことにより生じたものである

\section{結 論}

本研究では以下の知見を得た。

（1）建物保全現場での故障・不具合の記録業務について、一般にどの 程度の水準で遂行されているかを調べるため、大規模から小規模まで 13 件の事務所建物で聞き取り調查を行った。多くの建物でこのような 記録は高い水準でなされており、重要な業務と位置付けられていると 考えられる。従って、本研究に用いているような保全記録は珍しいも のではない。しかし、著者らが調査研究の対象とした建物以外では、 データの提供はできないとのことであった。保全記録データ自体が希 少なのではなく、研究に提供されるデータが希少なのであることが明 らかになった。

（2）某大規模事務所建物の故障・不具合についての保全記録データを 調查分析対象とした。この記録は建物竣工以来、約 11 年の長期にわ たり、ごく些細な事象をも含んでいる。記録された故障・不具合は総 件数で 10,937 件である。故障・不具合発生の特徴に関して、

i ）建物、設備区分別発生件数、矅日別、1 日の時間帯別、建物階別 （建物用途別）などの発生件数、また、発生間隔の分布を示した。

ii ）故障・不具合の発見区分として、居住者からの「申告」、ビルオ ートメーションシステムからの「アラーム」、建物保全関係者による 「発見」の別を示した。全体では居住者満足度に影響の大きい「申告」 が $65.6 \%$ 占めている。

iii）竣工から 1 年間の初期故障期について平均故障率の推移を実績デ 一夕に基づく回帰式（ $\mathrm{R}^{2}=0.8093 ）$ として捉えた。

(3) 使用した保全記録データは故障・不具合発生時刻と修復完了時刻 とが含まれており、また、修復を外注した場合には外注先も記録され ていた。このようなデータの分析から以下の知見が得られた。 
i ）修復に要した日数の分布を示した。大方の故障は短時間で復旧す るが、修復に長時間要するものも少数存在するという信頼性工学で知 られる保全時間の分布の特徴に共通する。

ii ）外注率を建物・設備区分別に見ると、エレベータを含む機械設備 の外注率のみが特段に高いが、他は大きな相違がない。また、故障・ 不具合の原因区分別に見ると、設備故障（機械的、電気的故障）の場 合のみ外注率が $50 \%$ を超える。

iii）外注、非外注の別に修復に要した日数の分布は、1 日で終了寸る 故障・不具合の久非外注の件数が多く、2 日以上を要するものは外注 の件数の方が多い。建物、衛生、空調、電気を個別に見ると、それぞ れの外注率は $20 \%$ を若干超える程度で差は小さい。いずれにおいても 修復を外注している場合の方が修復日数が長くかかっている。建物、 設備種別毎に、外注、非外注での平均修復日数の比較を示した。

iv）故障・不具合のモード区分別の件数を外注と非外注の件数を分け て示した。モードとして特に件数が多いのは動作不能であり、機能低 下がこれに次いでいる。外注率が高いのは、ガス漏孔、読值異常、制 御不能、蒸気漏れ、などである。

v ）空調設備について、機器の製造メーカーあるいはその関連会社等 によるサービスメンテナンスの利用状況を調べたところ、機器メーカ 一への外注は $10 \%$ 。計装会社への外注は $16 \%$ であった。調査建物で は地域熱供給を受けており熱源機器が無いため、2 次側ではこのよう に少なく、多くは工事会社に外注されている。

\section{謝 辞}

第 2 節の故障・不具合に関する記録の水準に関する調査は、全国ビ ルメテデンイ協会の中村孝之氏のご助力を得た。また、この調査には、当 時、東洋大学工学部建築学科卒論生の覚張寛也君（現、日本空調开一 ビス）の貢献が大きい。記して謝意を表する。

\section{注}

1）建物には修理系の能動機器の機能に係わる、すなわち信頼性理論の対 象となるような「故障」以外に、多くの様々な不具合が発生する。例え ば、大便器に携帯電話を落としたというような場合、取り出すのを保全 員に頼るため保全員の稼働が発生する。本論文で「故障・不具合」とは、 保全記録に残る保全員の稼働が発生した全ての事象を指寸。但し、蛍光 管の取替えは別途管理のため含めていない。

2) 本研究は文献 1) 2) 3) と一連の研究を成す。一貫した目的は、保全計画 のための資料提供である。文献 1）では不具合対応の保全効果検証とい う観点から、特に居住者の満足度との関係を念頭に修復時間に焦点を当 てて分析した。文献 2）では不具合の発生実態とこれに対処する保全の 業務の量的負担の状況を分析した。文献 3）では文献 2）の後半の研究 を発展させ、保全現場における繁忙状況が故障・不具合修復に要する時 間に与える影響を定量化する方法を示した。

本研究では、故障・不具合発生間隔や修復時間の分布関数などによる 定量的把握、また初期故障期の特性や外注状況などの定量的把握を試み た。これらをデータ分析の課題として設定するに当たり、仮に、モンテ カルロ法により故障・不具合の発生とその修復をシミュレーションする ことを想定し、これに必要な基礎資料の蓄積を意図した。ここで仮想し たシミュレーションが実現すれば、様々な保全計画において、例えば文 献 12）の研究のように最適化をはかることが容易になると考えられる。 文献 1)〜3) および本論文において調查対象とした建物はそれぞれ全 て異なる。いずれの調査建物も特殊性の少ない事務所ビルであり、個々 の知見はある程度の一般性を有すると考えられる。従って、これら一連 の研究で得られた知見は、建物所有者や居住者等による建物評価におい
てベンチマーク的な資料ともなるものである。

3) 図 6 から分かるように、故障・不具合は居住者から知らされる場合が 最も多く、建物保全担当者の巡回点検等で発見される場合がこれに次い でいる。土日および平日の夜間には、居住者も保全担当者も少ない。こ のため、人為的原因で発生する故障・不具合が少なく、また故障・不具 合が発生していてもこれに気付く人が少ない。平日の昼休みは、点検作 業が休止し、居住者による通報も少なくなる。従って故障・不具合確認 件数が減少する。図 3 、図 4 のデータは保全担当者のローテーション計 画などのための基礎資料として有用と考えられる。

4 ）通常、大規模建物のビルメンテナンスでは、建物竣工後 1 年間程度は 故障・不具合が多発し、現場が多忙となることを考慮し、応援の保全員 を加える。保全計画において、この応援の稼働量を過不足無く推定寸る ためには、このような資料が不可欠である。

5 ）故障・不具合の修復に要した時間は、例えば近年注目されている SLA /KPI (Service Level Agreement/Key Performance Indicator) にお ける KPI の一つとして重要である。修復に要した時間の評価においては、 平均值だけでなく分布状況も含めて評価され㸚ばならない。本論文で示 した資料は、評価のベンチマークとなると考えられる。

6 ) 故障・不具合のモード区分は保全記録データにおける分類による。「暑 い寒い」は代表的な居住者からのクレームである。空調機能の問題の こともあるが、設定不良や個人の温熱感選好の問題の場合も多く、原因 が多様である。このため独立した項目としている。「制御不能」は「動 作不能」に含まれるべきと考えられるが、制御は技術分野として特化し 外注先も限られその管理の都合などのため独立した項目となっている。 このようなモードの分類は保全現場の長年の経験に基づくものであり、 これを尊重し本論文では保全記録の分類をそのまま採用した。

\section{参考文献}

1）小松佳正, 高草木明 : 事務所建物における不具合発生と常駐管理者に よる対応の実態に関寸る調査研究, 日本建築学会計画系論文集, N0. 540, pp. 259-265, 2001.2

2）小松佳正, 高草木明 : 中小規模事務所ビルにおける不具合発生と建物 管理者による対応の実態に関する調查研究, 日本建築学会環境系論文集, N0. 574, pp. 161-168, 2003. 12

3）高草木明, 大澤昌志、佐々木有生 : 大規模事務所建物の保全現場にお ける繁忙状況の故障・不具合修復に要する時間への影響に関する研究, 日本建築学会計画系論文集，No. 616，pp. 141-151，2007.6

4) 高草木明, 西千春, 本田精一, 小泉幸秀: 建築設備の保全と管理の契 約のための業務品質水準設定方法, 日本建築学会技術報告集, 第 25 号, pp. 197-202, 2007.6

5）JIS 信頼性用語基本・一般編（Z8115-1981），日本規格協会，1981

6) 村上公哉, 尾島俊雄 : 某ビルにおける建物部位の保全要因の発生過程と その特性に関する研究, 日本建築学会計画系論文報告集, No. 427, pp. 119-128, 1991.9

7）村上公哉, 尾島俊雄, 竹林芳久, 高部素行 : 建物の保全費用からみた 物理的要因の機能劣化に関寸る研究, 日本建築学会計画系論文報告集, No. 418 ， pp. $115-124 ， 1990.12$

8）竹林芳久 ・尾島俊雄・村上公哉・佐藤文人 : 某ビルの更新時における 劣化要因別・部位別の保全費用構成に関寸る調查研究, 日本建築学会計 画系論文報告集，No. 431，pp. 129-136，1992.1

9) 高草木明 : 空調設備の物理的劣化の回復のための保全費用に関する調査 研究, 日本建築学会計画系論文集, No. 459, pp. 27-36, 1994.5

10)森口繁一編 : 品質管理講座新編統計的方法, 日本規格協会, 1993 11) 市田嵩：改訂保全性工学入門, 日科技連, 1990

12) Ro-Yeul Kwak, Akira Takakusagi, Jang-Yeul Sohn, Shuji Fujii, Byung-Yoon Park, " Development of an optimal preventive maintenance model based on the reliability assessment for air-conditioning facilities in office buildings" , Building and Environment, E1sevier Ltd., pp. 1142-1156, 2004. 10 